\title{
Cutaneous myasis in trophic leg ulcers
}

\section{Patricia Chang1', Gustavo Adolfo Oliva Vega², Edlin Mayté Lizama Auyón²}

${ }^{1}$ Department of Dermatology, Hospital General de Enfermedades IGSS and Hospital Ángeles, Guatemala, ${ }^{2}$ Hospital General de Enfermedades IGSS and Hospital Ángeles, Guatemala

Corresponding author: Dr. Patricia Chang., E-mail: pchang2622@gmail.com

An 80 year-old male patient is brought to the emergency department due to his nephew noticing a putrid smell coming from the patient's leg ulcers. The patient's family had abandoned him 9 months ago and thus lived alone. Local debridement was performed on the ulcers and a culture was taken. Due to poor health conditions, he was transferred to the general medicine ward. There he received treatment for his Type-II Diabetes and chronic kidney failure.

On physical examination, the patient was in poor health conditions with dermatosis located in both lower extremities but mainly on the right one. Both legs presented numerous, well-circumscribed ulcers with fibrinous tissue as well as a mobile whitish larvae moving in one of the ulcers (Fig. 1) and multiple whitish parasites (Fig. 2). Time since onset of the current clinical presentation was unknown.

Relevant comorbidities included: Type-II Diabetes with onset 15 years ago, as well as KDOQI V Chronic Kidney Failure and obstructive pulmonary disease. The following diagnoses were made: cutaneous myasis, sepsis, Type-II Diabetes and chronic renal failure.

On admission, laboratories and cultures were performed. Relevant values are as follow: Hemoglobin $-7.77 \mathrm{~g} / \mathrm{dL}$, Hematocrit - 23.93\%, BUN - 65 mg/dL, Creatinine $1.31 \mathrm{mg} / \mathrm{dL}$. P. aeruginosa was isolated in the culture. On a microscopic analysis, a larva with two oral hooks was seen (Fig. 3) and a histological analysiswas later performed on it (Fig. 4).

The following diagnoses were now made: cutaneous myasis, P. aeruginosa-induced sepsis, Type-II Diabetes and uncontrolled chronic kidney failure. The following medications are begun: Meropenem 500mg IV TID, Amikacin $500 \mathrm{mg}$ IV BID, hemodyalisis thrice per week and Erithropoietin 2000U SC thrice-in week. Regrettably, the patient died 8 days after admittance.

Myasis is described as an infestation of vertebrated animals and humans by larvae coming from dipters (flies) which feed on live and dead tissue cells of the host.Depending on the cause of the myasis, the flies

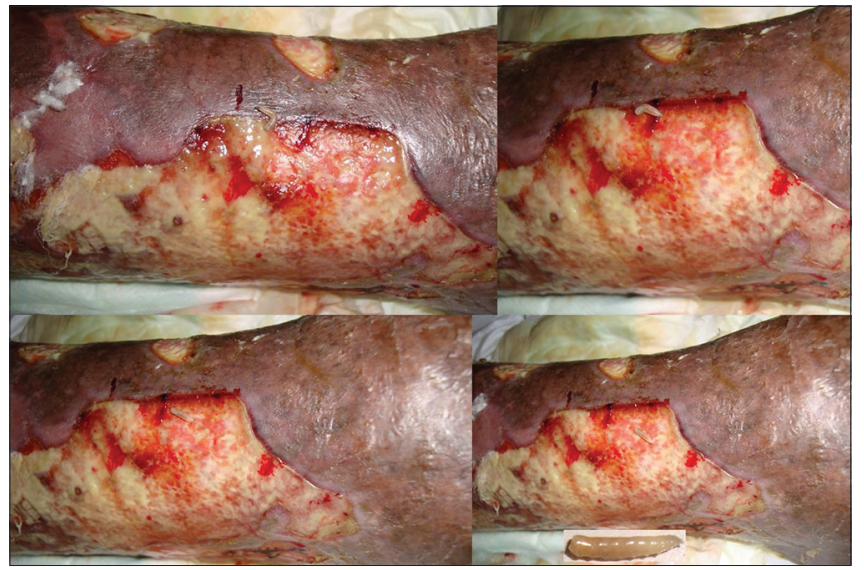

Figure 1: Larvae in movement within a trophic ulce.

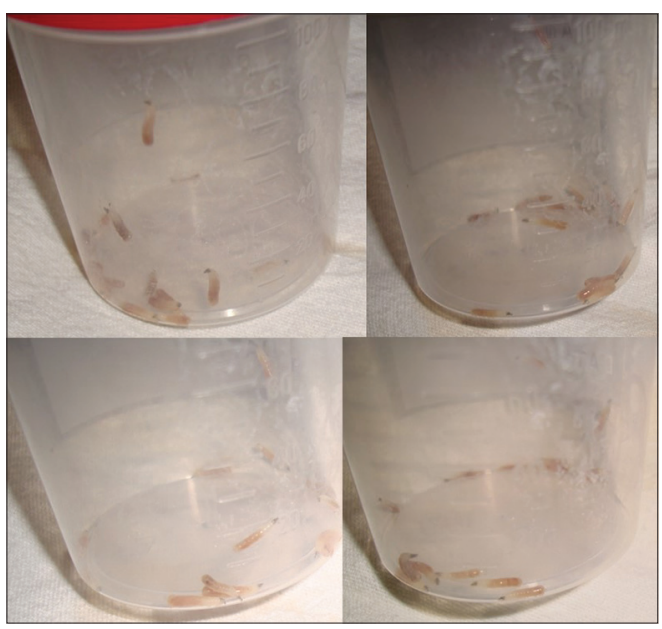

Figure 2: Multiple larvae extracted from the ulcer.

\footnotetext{
How to cite this article: Chang P, Oliva Vega GA, Lizama Auyón EM. Cutaneous myasis in trophic leg ulcers. Our Dermatol Online. 2016;7(4):472-474. Submission: 20.01.2016; Acceptance: 29.03.2016 DOI: 10.7241/ourd.20164.128
} 


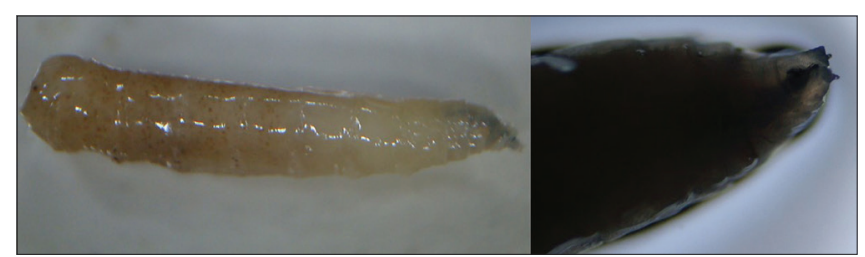

Figure 3: On microscopic analysis, the presence of oral hooks.

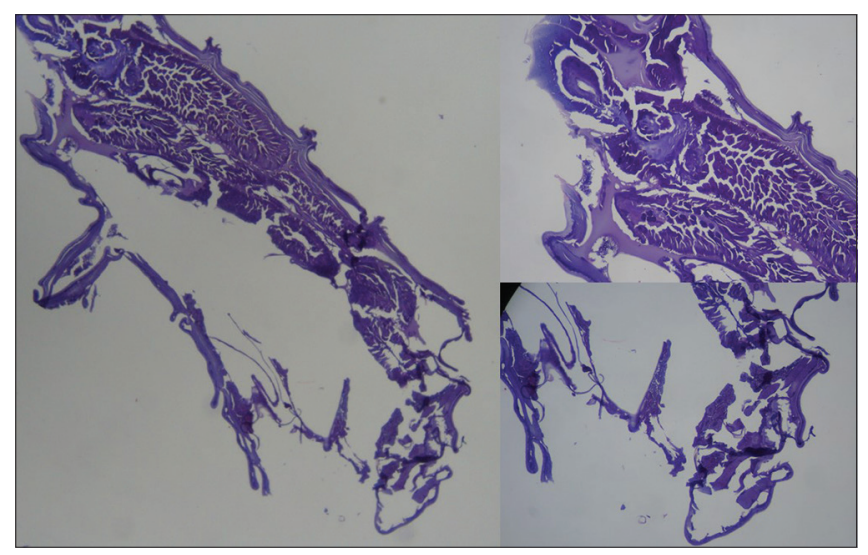

Figure 4: Histopathological aspect of the larva.

are categorized into three groups according to their parasitic relationship with the host in: obligatory parasites, facultative parasites and accidental parasites. The main responsible for furunculous myasis in México, Central America and South America is the Dermatobia hominis fly. From the moment of infection onwards, the larvae will remain in the hostfor 5-12 weeks; period in which it reaches sufficient maturity to leave the host during the night in order to become an adult fly after a month [1-3].

It is more common to become infected during summer. These infestations tend to occur in weakened people or in those who do not heal their wounds. It occurs in both sexes and in any age but it becomes more frequent in people with low socioeconomic status $[2,3]$.

Clinically, myases can be divided according to the site in which they develop in: cavitary, cutaneous and intestinal myasis. Cutaneous myases can further be divided into furunculous or wound-related subtypes [2,3].The initial lesion is a small erythematous papule, which grows until it becomes a node with a diameter between 3-12 mm. These lesions are found in exposed body parts. Normally only one lesion is found, but in some cases there can be multiple lesions and the skin between them will usually be indurated by inflammatory tissue. These lesions may be asymptomatic, but in most caseswill cause itchiness followed by local pain and a sensation of "something moving below the skin". Serous exudate is frequent and the patient may present enlarged lymph nodes, fever and general malaise [3-5].

The diagnosis is clinical and based on the patient's history, prior comorbidities, symptoms and injury characteristics. An important sign is the discovery of a lone furuncle with antibiotic resistance and the presence of a small pore within it, with serous exudate and sensation of a foreign body moving below the skin. The definitive diagnosis is made with direct visualization of the larvae via microscopy. A patient usually harbors between 1-8 larvae. Laboratory examination usually reveals leukocytosis and eosinophilia [4].

The treatment consists in the extirpation of the larvae via incision or direct pressure over the furuncle in order to expel the parasite. Afterwards it is necessary to close the respiration orifice of the larvae with solid Vaseline, oil or liquid wax. Local application of aniseed essence makes the parasite evacuate due to it being neurotoxic. 1\%-Ivermectin in a propylene glycol solution, 5\%-chloroform in olive oil or ether has also been used to paralyze the parasite. After the larva is removed, the node spontaneously resolves without leaving a scar [6].

Mortality for this disease is around $10 \%$ and often associated with CNS injuries. The use of screens and flytraps is recommended and care must be taken to cover any wound to prevent it from becoming an entry-point for the infection. The most important complications are overlying bacterial infection or tetanus $[7,8]$.

\section{REFERENCES}

1. Cruz Reyes A, Camargo B. Parasitology and related sciences glossary. 1st ed. Mexico; 2001: v.1 p 151-2.

2. Alcalá D, Yánez S. Furunculous myasis caused by Dermatobia hominis. Rev Cent Dermatol Pascua (Mexico). 2006;15:23-5.

3. Chanccour C. Forunculous myasis: Forunculous myasis-case series of five patients belonging to the Pemon ethnic group and literature revision. Venezuelan Rev. Dermatology (Venezuela). 2005;43:8-15.

4. Calleja Pascual JM, Pérez Urrutia E, Calvo Gainzarain C, Lecuona Irigoyen A, Miskovic N, Iturralde iriso J. Forunculous myasis caused by Dermatobia hominis in a tropical country tourist. Gac Med Bilbao (Spain). 2008;105:100-4.

5. Contreras Ruíz J, Arenas Guzmán R, Vega Memije ME, Castillo Díaz M. Forunculous myasis caused by Dermatobia hominis. A mexican, costarican-imported case. Gac Méd Méx (Mexico). 2004;140:81-4.

6. Moya J, Spelta MG, Gavazza S, Barbarulo A, Fontana MI, Barerra M, Lafo jurjo L, et al. Cutaneous myasis: a literature revision and 
www.odermatol.com

presentation of a forunculous myasis case. Arch Argent Dermatol (Argentina). 2007;57:217-23.

7. Pastor C, Briceño G, Schafer F. Forunculous cutaneous myasis caused by Dermatobia hominis. Rev Med Chile (Chile). 2013;141:1081-2.

8. Allevato M. Myasis. Act Terap Dermatol (Buenos Aires). 2005;28:272-9
Copyright by Patricia Chang, et al. This is an open access article distributed under the terms of the Creative Commons Attribution License, which permits unrestricted use, distribution, and reproduction in any medium, provided the original author and source are credited.

Source of Support: Nil, Conflict of Interest: None declared. 